\title{
THE IMPACT OF BASEL BANKING REGULATION ON FINANCIAL TRANSACTIONS
}

\author{
Margit CSIPKÉS, Rebeka NAGY, Sándor NAGY \\ University of Debrecen Faculty of Economics Institute of Statistics and \\ Methodology, Debrecen, Hungary \\ csipkes.margit@econ.unideb.hu \\ nrebeka96@gmail.com \\ nagysanyi@freemail.hu
}

\begin{abstract}
In our research, we review Basel banking regulation because in our rushed lives, unfortunately, we don't know much about it (even though we live in a world controlled by money). In our research, we aim to present in detail the centuries-old system of the banking system, the role of banks in the economy and society, and the need for banking regulation in the light of the operation of credit institutions. In our research, we review in detail the past of Basel banking regulation and examine its impact on the present. In our material, we have summarized in a separate section the most well-known forms of classification, which can be used in such an analysis due to their complexity. We also present the CAMELS method, which, unlike other methods of analysis, includes the classification of capital adequacy, assets, management, profitability, liquidity and sensitivity to market risks. In our research, we present the CAMELS analysis method (supported by indicators) through a specific example. The CAMELS method was developed in the United States in order to determine a bank's capital adequacy. In addition, the method helps to determine the quality of assets, profitability and liquidity (it is also suitable for determining the sensitivity to market risk). Our aim through this research is to present both the advantages and disadvantages of the CAMELS method through the example of a reputable bank in the last 5 years. Officially available databases were used for the research.
\end{abstract}

Keywords: Basel, Camels, analysis method, research

\section{JEL classification: G21}

\section{Introduction}

Nowadays, people take the existence of banks completely naturally. We can either borrow from banks if necessary or save our money there. A significant part of today's society receives their income in a bank account and we also take care of everyday matters through this account. (purchase of goods, settlement of invoices, repayment of loans, etc.). The existence of credit institutions is essential for the functioning of the economy and society. Depending on the specific impact of credit institutions on a day-to-day basis, the need for banking regulation becomes clear. Until the end of the 20th century, banks were regulated at the nation-state level. However, banking regulation was unequal in terms of branches and international activity. The turning point was the adoption of the Basel Capital Accord, which raised the regulation of credit institutions to an international level and set uniform standards for the regulatory system. 


\section{Literature - A Basel I-IV. brief overview}

The International Convergence of Capital Measurement and Capital Standards was established by representatives of the 12 largest capital market countries (France, Italy, Germany, Sweden; Canada, Japan, Netherlands, Luxembourg, Switzerland, USA, United Kingdom, Belgium) to ensure uniform competition (Tajti, 2011).

The Basel I agreement was issued in 1988. The agreement focused on the capital adequacy of financial institutions. By defining the concept of own funds, this agreement created elements of guarantee capital that provided creditable collateral to credit institutions to cover future losses.

The reason for the development of the new banking regulatory system is the shortcomings of Basel I. (BCBS 2006). On 26 June 2004, the Basel Committee on Banking Supervision established Basel II. This agreement already takes into account banks' operational risk, credit risk and market risk. The new banking regulation also provides for additional capital, which is accepted by national regulators. A major disadvantage of the regulation is that Basel II. capital requirements do not include liquidity risk, banking book interest rate risk, strategic risk and business risk (these risks would be subject to the "supervisory review process"). This regulation requires banks to maintain their capital adequacy requirement at a minimum of $8 \%$ (Tajti, 2011; Fazekas, 2009). Basel II provided banks with more informed approaches to calculating capital requirements based on credit risk. It aims to provide users of financial information with relevant information to make informed trading decisions (Hull, 2015). (Hull, 2015).

Following the economic crisis of 2008, Basel II Convention has been revised. Basel III was developed. agreement. The aim of Basel II is to improve the ability of banks to deal with shocks arising from financial stress, to make the system more transparent and to make them more public. It is important to prevent banks from taking more risk than they can handle (Homolya, 2014; Szombati, 2010). Basel III. the most important principles of Basel I and II. are based on principles. It is important to introduce a minimum capital requirement, a leverage ratio and liquidity in banks. Basel III. its capital requirements focused on reducing customer risk. This risk depended on whether the bank traded through a merchant or with a central clearing partner. If a bank has traded derivatives with the trader, Basel III. created an obligation and imposed a high capital requirement for this trade.

In December 2017, the Governors and Supervision Groups of the Central Bank adopted the Basel IV reform package. The main objectives of the latest reforms are to increase the risk sensitivity of standardized approaches and to increase the comparability of RWA calculations by limiting the use of internal models. Basel IV. package proposes a nine-year implementation timetable, which leaves considerable time for preparation. A five-year "implementation" period will begin on January 1, 2022, with full implementation expected from January 1, 2027. In summary, Basel IV credit risk is a challenge for any financial institution (KPMG, 2013; 2015; Coluccia-Franchini-Quinto, 2020).

\section{Material and methodology - Analysis and components of Camel}

In 1979, the Unified Classification of Financial Institutions (UFIRS) was introduced. The system has become internationally known by the acronym CAMEL, which 
reflects five areas of evaluation: Capital Adequacy (C), Assets Quality (A), Management (M), Earning (E), Liquidity and assets and liability management (L). In 1995, the name CAMEL was changed to CAMELS. The meaning of "S" stands for subjectivity to market risk (Sensitivity). The new rating includes an assessment of exposure to market risk and adds a rating on a scale of 1 to 5 to market risk management. CAMEL is used by banking supervisors to rate financial institutions based on six factors (Sulyok - Pap, 2006; Seregdi, 1993).

Next, let's look at the 5 assessment areas:

1. capital adequacy: Capital adequacy shows the stability of a company when faced with special risks. Capital adequacy shall reflect the effectiveness of the credit institution's investment policy and practices (Szemán, 2015; Rai, 2010). The "capital adequacy ratio", "leverage ratio" and "capital accumulation ratio" can be used for the analysis. Qualitative assessment of capital adequacy: 1 strong capital level, 2 satisfactory capital level, 3 below-satisfactory capital level (but still exceeding the statutory level), 4 incomplete capital level (external financial resources may be required), 5 critical capital level (requires immediate financial assistance) (Szemán, 2015; Rai, 2010).

2. device quality: Asset quality refers to the quality of institutional credit that reflects the income of the institution. This shows the stability of the company when faced with special risks. Indicators that can be used in the analysis are "rated credit ratio", "outstanding loan ratio indicator" and "adjusted credit quality indicator". Asset quality classification in the analysis: 1 excellent asset quality (risk exposure is negligible compared to management ability), 2 satisfactory asset quality (risk exposure is proportional to management skills), 3 asset quality below satisfactory (means deterioration and increased risk), 4 insufficient asset quality, 5 already critically insufficient asset quality (Szemán, 2015; Rai, 2010).

3. management: Management evaluation determines whether an institution is able to respond adequately to financial difficulties. The indicators used in the analysis are "headcount efficiency" and "cost-effectiveness". Quality classification of management in the analysis: 1 strong managerial performance (strength of risk management), 2 adequate managerial performance and well-identified risk, 3 improvement of managerial performance and poorer-than-satisfactory risk management, 4 deficient performance (to maintain stability) management must intervene), 5 means critically deficient managerial performance (requires replacement or strengthening of management) (Szemán, 2015; Rai, 2010).

4. profitability: The ability of a credit institution to generate adequate returns for expansion, maintaining competitiveness and raising capital. The indicators used in the analysis are "return on equity (ROE)" and "return on assets (ROA)". Profitability classification in the analysis: 1 strong profitability (this level has more than enough income for proper operation and adequate level of capital), 2 satisfactory profitability (income is just enough to operate and maintain capital level), 3 means profitability that already needs to be increased (there is not enough income for operation and capital growth), 4 already low level of profitability (net income and loss fluctuate at this level, there is not enough income for operation and capital maintenance), 5 critical illness (credit institution is unprofitable, viability uncertain) (Szemán, 2015; Rai, 2010).

5. liquidity: A credit institution can be considered liquid if it is able to repay the deposits placed with it and the interest thereon and to provide credit to creditworthy customers. Following the 2008 financial crisis, the Basel Convention 
required credit institutions to calculate liquidity ratios. The indicators used in the analysis are "liquidity ratio" and "deposit coverage ratio". Liquidity rating in the analysis: a rating of 1 means strong, a rating of 2 means satisfactory liquidity and advanced funding. For a rating of 3 , both liquidity and funding practices need to be improved. A rating of 4 indicates an insufficient level of liquidity, in which case the funding process is inadequate. A rating of 5 indicates a critical level of illiquidity and an inadequate funding approach where the credit institution is at risk. In such cases, it needs immediate external financial assistance and the mobilization of resources to pay overdue liabilities (Szemán, 2015).

6. Sensitivity to market risks: Sensitivity examines how individual risk exposures can affect institutions. The indicators used in the analysis are "interest rate risk" and "price risk". Classification of sensitivity to market risks in the analysis: 1 the bank's risk management is effective, the income level and capital provide coverage in proportion to the risks taken, 2 the risk management is satisfactory compared to the size of the bank, 3 one or more elements need to be developed, 4 significant market risk exposing the credit institution to liquidity, 5 critical deficiencies are present in the credit institution that threaten operations, management is unable to manage risks, unsuitable for it) (Szemán, 2015). In the following, we present the CAMELS analysis at OTP Bank. The question has arisen in us as to whether it is necessary to obtain the best rating for all factors in order to maintain a market-leading position.

\section{Material and methodology - Analysis and components of Camel}

OTP Bank is at the forefront of the 2019 ranking of domestic credit institutions on the basis of bank balance sheet total and after-tax profit. In the case of the comparative analysis, the average of the banking sector is the average of the 3 market-leading banks (UniCredit Bank, Erste Bank and K\&H Bank) following OTP Bank.

\subsection{Examination of capital adequacy}

In the case of the examination of long-term solvency, it can be stated that OTP Bank's capital adequacy ratio shows a decrease and then an increase in the period under review (Table 1). The average for the banking sector as a whole showed higher result, but also fluctuated in both directions. The increase was due to an increase in own funds.

Table 1: Indicators related to capital adequacy between 2015-2019 (\%)

\begin{tabular}{|l|c|c|c|c|c|c|c|c|c|c|}
\hline \multirow{2}{*}{ Indicators } & \multicolumn{4}{|c|}{ OTP Bank } & \multicolumn{4}{c|}{ Average of the banking sector } \\
\cline { 2 - 13 } & $\mathbf{2 0 1 5}$ & $\mathbf{2 0 1 6}$ & $\mathbf{2 0 1 7}$ & $\mathbf{2 0 1 8}$ & $\mathbf{2 0 1 9}$ & $\mathbf{2 0 1 5}$ & $\mathbf{2 0 1 6}$ & $\mathbf{2 0 1 7}$ & $\mathbf{2 0 1 8}$ & $\mathbf{2 0 1 9}$ \\
\hline Capital adequacy & 16,2 & 16 & 14,6 & 18,3 & 16,3 & 17,9 & 17,8 & 19,8 & 18,7 & 19,2 \\
\hline Leverage & 17,9 & 18,4 & 18,6 & 18,2 & 18,2 & 6,03 & 6,8 & 9,02 & 7,4 & 9,41 \\
\hline Capital accumulation & 5,12 & 14,3 & 17,2 & 17,4 & 18 & 6,29 & 16,1 & 15,6 & 17,1 & 14,1 \\
\hline
\end{tabular}

Source: Own compilation based on the 2015-2019 annual reports of OTP Bank, ERSTE Bank, Unicredit Bank and K\&H Bank

The average indicators of the banking sector proved to be better in the period under review, while the indicators of OTP Bank were lower in the period under 
review. It exceeded the minimum capital adequacy ratio under the Basel Convention in all three years. Based on these, it can be stated that OTP Bank can be considered a capital-intensive bank, there is no risk of insolvency. This capital adequacy is also valid for the other banks of the examined banking system, we can see from the data that the Hungarian banking system has produced strong, good results so far. It received 1 rating for the capital adequacy test.

\subsection{Examination of asset quality}

In order to examine the maintenance of solvency, the indicators in Table 2 were calculated.

Table 2: The examined indicators in the period 2015-2019 (million HUF/person)

\begin{tabular}{|l|c|c|c|c|c|}
\hline \multirow{2}{*}{\multicolumn{1}{|c|}{ Indicators }} & \multicolumn{5}{c|}{ OTP Bank } \\
\cline { 2 - 6 } & $\mathbf{2 0 1 5}$ & $\mathbf{2 0 1 6}$ & $\mathbf{2 0 1 7}$ & $\mathbf{2 0 1 8}$ & $\mathbf{2 0 1 9}$ \\
\hline Qualified loan ratio & 13,5 & 12,5 & 12,3 & 11,6 & \\
Description indicator & 31,4 & 10,8 & 9,98 & 9,75 & $\begin{array}{c}\text { not data } \\
\text { available }\end{array}$ \\
\hline Adjusted credit quality & 6,34 & 9,5 & 8,4 & 6,2 & \\
\hline
\end{tabular}

Source: Own preparation based on OTP Bank's annual reports for 2015-2019

OTP Bank's qualified loan portfolio developed favorably between 2015 and 2018, and the willingness of borrowers to repay was also reflected in the continuous decline in percentages. In $2018,11 \%$ of repayments will have a repayment problem. Overall, with regard to OTP Bank's average, the share of loans with a capital debt of more than 15 days decreased.

A decrease can also be observed in the "Description ratio". Despite an increase in the number of borrowers, the proportion of those making late payments has decreased. The improvement is small. The adjusted credit quality ratio is low throughout the period under review.

Table 3: Lending data of OTP bank between 2015-2019 (\%)

\begin{tabular}{|l|c|c|c|c|c|}
\hline \multicolumn{1}{|c|}{ Indicators } & $\mathbf{2 0 1 5}$ & $\mathbf{2 0 1 6}$ & $\mathbf{2 0 1 7}$ & $\mathbf{2 0 1 8}$ & $\mathbf{2 0 1 9}$ \\
\hline $\begin{array}{l}\text { Rate of loans overdue for more than } \\
\text { 90 days }\end{array}$ & 17,0 & 14,7 & 9,2 & 6,3 & 4,2 \\
\hline $\begin{array}{l}\text { Coverage of loans overdue for more } \\
\text { than 90 days with all provisions }\end{array}$ & 93,4 & 96,8 & 99,3 & 118,4 & 142,37 \\
\hline
\end{tabular}

Source: Own preparation Based on the 2015-2019 annual reports of OTP Bank

Table 3 shows that the proportion of loans overdue for more than 90 days decreases over the five years examined. Changes in the coverage of loans overdue for more than 90 days with all provisions are also encouraging for the future.

The bank's rated loan composition changed relatively much during the period under review. The receivables to be monitored separately have almost halved in 
the last 3 years. Loans classified as below average brought the same level, while transactions in the doubtful category, ie arrears with a principal of between 3 months and 1 year, showed a high increase. In my opinion, this is due to the fact that in the years following the 2008 crisis, borrowers became more cautious in the post-forint period, but this trend has come to an end in recent years and people by being able to repay loans as general dangers such as job losses and repayment of preferential family support loans in the event of a divorce remain a real problem. In terms of asset structure, OTP Bank has a variable composition. Most of the loans are loans. Asset quality can be rated 2 for the period under review.

\subsection{Management examination}

The management of the credit institution plays a significant role in the life of all commercial banks, therefore we examined both the staff efficiency and cost efficiency indicators. The headcount of the OTP Bank Group developed as follows in the years under review.

Based on the headcount efficiency indicator 1, the increase in lending can be seen in the period under review. With a few minor exceptions, all commercial banks have increased their staff over the past five years. OTP Bank produced lower indicators compared to the average of the banking sector. Regarding the 2 indicators, the average of OTP Bank and the benchmark also shows a steady improvement.

Table 4: Personnel efficiency indicators (LH) in the period 2015-2019

\begin{tabular}{|c|c|c|c|c|c|c|c|c|c|c|c|}
\hline \multirow{2}{*}{\multicolumn{2}{|c|}{ Indicators }} & \multicolumn{5}{|c|}{ OTP Bank } & \multicolumn{5}{|c|}{ Average of the banking sector } \\
\hline & & 2015 & 2016 & 2017 & 2018 & 2019 & 2015 & 2016 & 2017 & 2018 & 2019 \\
\hline \multirow{2}{*}{$\begin{array}{l}\text { Head- } \\
\text { count }\end{array}$} & 1 & 141,6 & 146,9 & 168,3 & 202 & 306,4 & 477,7 & 498,4 & 471,4 & 526,6 & 579,9 \\
\hline & 2 & 209 & 221,4 & 246,5 & 280,8 & 388,4 & 603,5 & 658,1 & 689,2 & 769,6 & 875,4 \\
\hline
\end{tabular}

Source: Own compilation based on the 2015-2019 annual reports of OTP Bank, ERSTE Bank, Unicredit Bank and K\&H Bank

Cost-effectiveness shows a slight fluctuation in the average of both OTP Bank and the banking sector (Table 5), which is due to the fact that the bank's balance sheet total increased more than the increase in operating expenses in some places and turns in the opposite direction.

Table 5: The cost-effectiveness indicator for the period 2015-2019

\begin{tabular}{|l|c|c|c|c|c|c|c|c|c|c|}
\hline \multirow{2}{*}{ Indicator } & \multicolumn{4}{|c|}{ OTP Bank } & \multicolumn{4}{c|}{ Average of the banking sector } \\
\cline { 2 - 11 } & 2015 & 2016 & 2017 & 2018 & 2019 & 2015 & 2016 & 2017 & 2018 & 2019 \\
\hline CE (\%) & 27,32 & 27,99 & 29,86 & 29,37 & 35,45 & 34,24 & 40,95 & 36,78 & 38,53 & 41,62 \\
\hline
\end{tabular}

CE: Cost-effectiveness

Source: Own compilation based on the 2015-2019 annual reports of OTP Bank, ERSTE Bank, Unicredit Bank and K\&H Bank 
Efficacy indicators were then examined. The branch efficiency indicator 1 shows that more and more loans were received per unit of bank branches, which was due to the rising loan portfolio (Table 6). The provision of family support and preferential loan disbursement by the Hungarian Government in 2018 enabled banks to significantly increase their lending, which results in a huge jump. At the same time, customer deposits have been growing steadily, as provided by the second indicator of account efficiency. There is an increase in the average labor cost. This resulted in a stable positive change in average labor costs. Based on these indicators, it can be stated that the management of OTP Bank operates the credit institution properly (from 2018 to 2019, the network was expanded with 323 branches). The management can be classified as 1 in the period under review.

Table 6: Efficiency indicators at OTP Bank in the period 2015-2019

\begin{tabular}{|l|c|c|c|c|c|}
\hline \multirow{2}{*}{\multicolumn{1}{|c|}{ Indicators }} & \multicolumn{5}{c|}{ OTP Bank } \\
\cline { 2 - 6 } & $\mathbf{2 0 1 5}$ & $\mathbf{2 0 1 6}$ & $\mathbf{2 0 1 7}$ & $\mathbf{2 0 1 8}$ & $\mathbf{2 0 1 9}$ \\
\hline Account efficiency 1 & 4037,29 & 4351,07 & 4696,13 & 5887,11 & 7063,16 \\
\hline Account efficiency 2 & 5989,13 & 6473,39 & 7013,80 & 8183,85 & 8951,93 \\
\hline Average wage cost / person & 3,59 & 3,60 & 3,86 & 4,55 & 5,36 \\
\hline
\end{tabular}

Source: Own preparation Based on the 2015-2019 annual reports of OTP Bank

\subsection{Examination of profitability}

Profitability is a vital issue for all commercial banks, as credit institutions aim to generate income. The most common indicators used to measure profitability are shown in Table 7.

Table 7: Development of profitability indicators between 2015-2019

\begin{tabular}{c|c|c|c|c|c|c|c|c|c|c}
$\begin{array}{c}\text { Indica- } \\
\text { tors }\end{array}$ & \multicolumn{4}{|c|}{ OTP Bank } & \multicolumn{4}{c}{ Average of the banking sector } \\
\cline { 2 - 11 } & 2015 & 2016 & 2017 & 2018 & 2019 & 2015 & 2016 & 2017 & 2018 & 2019 \\
\hline $\begin{array}{c}\text { ROE } \\
(\%)\end{array}$ & 5,1 & 15,3 & 18,5 & 18,7 & 20,3 & 8,93 & 18,6 & 16,6 & 18,4 & 15,2 \\
\hline $\begin{array}{c}\text { ROA } \\
(\%)\end{array}$ & 1,1 & 1,8 & 2,4 & 2,3 & 2,4 & 0,57 & 1,82 & 1,91 & 1,98 & 1,67
\end{tabular}

Source: Own compilation based on the 2015-2019 annual reports of OTP Bank, ERSTE Bank, Unicredit Bank and K\&H Bank

The ROE indicator shows the return on equity for the owners of the bank. The period under review was profitable for both OTP Bank and the average of the banks selected from the banking sector. The increase in the ROE ratio supports the bank's profitability. Comparing the data of OTP Bank with the further data of the banking sector, it can be said that it performed better, but in almost the same way, from the banking sector in the period under review. OTP Bank's results are steadily upwards. There is a slight fluctuation in the banking sector, but it can still be said to be profitable.

The ROA indicator shows the ratio of profit after tax to total assets. In terms of the calculated indicators, there are successful years behind commercial banks, OTP 
Bank's results in this category are also above the average of the banking sector, but along similar values. Profitability is rated 1 in the period under review.

\subsection{Liquidity analysis}

The report shows that the European Central Bank's refinancing resources, amounting to EUR 163 million, are available to the bank. There was no capital raising in 2018 due to the issuance of mortgage bonds due to central regulations. OTP Bank's liquidity reserve is significantly above the safe level. At the end of December 2018, it exceeded the amount of EUR 7.75 billion. This amount is orders of magnitude larger than the stock of maturing capital market debts. Regarding liquidity, it can also be said that in order to comply with the required liquidity ratio, mortgage bonds were issued in the nominal value of HUF 220 billion and repurchased from investors in the amount of HUF 52 billion in 2019 (Table 8).

Table 8: Liquidity ratios in the period 2015-2019 for the examined banks

\begin{tabular}{|l|c|c|c|c|c|c|c|c|c|c|}
\hline \multirow{2}{*}{ Indicators } & \multicolumn{4}{|c|}{ OTP Bank } & \multicolumn{4}{c|}{ Average of the banking sector } \\
\cline { 2 - 12 } & $\mathbf{2 0 1 5}$ & $\mathbf{2 0 1 6}$ & $\mathbf{2 0 1 7}$ & $\mathbf{2 0 1 8}$ & $\mathbf{2 0 1 9}$ & $\mathbf{2 0 1 5}$ & $\mathbf{2 0 1 6}$ & $\mathbf{2 0 1 7}$ & $\mathbf{2 0 1 8}$ & $\mathbf{2 0 1 9}$ \\
\hline Liquidity (\%) & 12,4 & 14,5 & 9,08 & 10,6 & 9,15 & 4,87 & 9,08 & 8,21 & 5,32 & 4,57 \\
\hline Deposit coverage (\%) & 68 & 67,2 & 68,2 & 69,9 & 78,9 & 81 & 76 & 68 & 67 & 65 \\
\hline
\end{tabular}

Source: Own compilation based on the 2015-2019 annual reports of OTP Bank, ERSTE Bank, Unicredit Bank and K\&H Bank

The deposit coverage ratio illustrates the strengthening of lending activity during the period under review. Considering the banking sector as a whole, this trend can be said to have strengthened lending in Hungary. Liquidity also includes the knowledge of the fact that the bond portfolio of households decreased by HUF 2 billion year-on-year, which is a $27 \%$ difference compared to previous years. Liquidity can be rated 1 during the period under review.

\subsection{Sensitivity to market risks}

In commercial banks, interest rate and price risk may arise (Table 9). In the case of OTP Bank, the interest rate risk ratio does not fluctuate much for the given period. The increase in the number of forint loans results in relatively equalized values. The bank's fixed-rate assets exceed the value of fixed-rate liabilities, ie fixed-rate loans are financed with floating-rate deposits. The low value of the deposit rate is affected by inflation and the fact that the central bank keeps the central bank base rate low. Savings are moving in the direction of securities investments and government securities, where there is the potential for higher returns relative to deposit rates. The banking group has an interest rate risk exposure, which is offset by the purchase of long-term, fixed-rate government securities, as the decline in yields has a negative impact on net interest income. In 2018, an interest rate swap was concluded with the Magyar Nemzeti Bank in the amount of HUF 299 billion. 
Table 9: Risk indicators in the period 2015-2019 for OTP Bank

\begin{tabular}{|c|c|c|c|c|c|}
\hline \multirow{2}{*}{ Indicators } & \multicolumn{5}{|c|}{ OTP Bank } \\
\cline { 2 - 6 } & $\mathbf{2 0 1 5}$ & $\mathbf{2 0 1 6}$ & $\mathbf{2 0 1 7}$ & $\mathbf{2 0 1 8}$ & $\mathbf{2 0 1 9}$ \\
\hline Interest rate risk (\%) & 244 & 215 & 196 & 180 & 168 \\
\hline Price risk (\%) & 0,09 & 0,09 & 0,09 & 0,12 & 0,1 \\
\hline
\end{tabular}

Source: Own compilation based on the 2015-2019 annual reports of OTP Bank, ERSTE Bank, Unicredit Bank and K\&H Bank

In terms of investments, the price risk is not significant, all data examined approach 0 percent due to the low investment rate. Sensitivity to market risk is rated 2 .

\subsection{The result of the qualification}

The CAMELS rating approach is seen as an important tool in identifying the financial strengths and weaknesses of a bank. This analysis highlights potential weaknesses and suggests the necessary corrective actions to overcome the weaknesses and thus improve a bank's overall performance.

Table 10: The CAMELS rating system for OTP Bank

\begin{tabular}{|l|c|c|c|}
\hline \multicolumn{1}{|c|}{ Appellation } & Rating & Weighting & Weighted value \\
\hline Capital adequacy (C) & 1 & $25 \%$ & 0,25 \\
\hline Asset quality A) & 2 & $20 \%$ & 0,4 \\
\hline Management (M) & 1 & $10 \%$ & 0,1 \\
\hline Earnings (E) & 1 & $20 \%$ & 0,2 \\
\hline Liquidity (L) & 1 & $15 \%$ & 0,15 \\
\hline Sensitivity (S) & 2 & $10 \%$ & 0,2 \\
\hline Total & & $\mathbf{1 0 0} \%$ & $\mathbf{1 , 3}$ \\
\hline
\end{tabular}

Source: Own editing

In the CAMELS rating system, a rating of 1 means a well-functioning, risk-free bank with appropriate risk management. The bank is shock-resistant and its lending capacity is favorable, and its capital adequacy represents good values. OTP Bank is able to maintain stable operations and carry out its activities smoothly even in a strong, unfavorable economic environment in terms of capital.

- The proportion of qualifying loans with adequate asset quality decreased, but the proportion of doubtful loans increased.

- In terms of liquidity, the bank is performing well.

- The management is suitable for leadership, performs its task well, is competent for this role in all respects.

- The banking group has an interest rate risk exposure, which is offset by the purchase of long-term, fixed-rate government securities.

OTP Bank's strengths: universal financial services through several subsidiaries; Hungary's largest commercial bank; more than 13 million customers; approx. It 
has 1500 branches; global presence in 9 countries; strong financial and brand position; appropriate strategy. Weakness of OTP Bank: strong competition means limited market share; downgrading recent credit ratings; characterized by dispersed ownership by private and institutional (financial) investors; domestic low interest rates; change in asset quality.

Opportunities for OTP Bank: further international expansion; merging banks; growth in demand for MNB credit and investment products.

The threat of OTP Bank: domestic political environment; diversified relations with other countries; strong competition in the region; public distrust of products and credit institutions.

\section{Conclusions and recommendations}

The aim of the research was to measure the stability of OTP Bank using the CAMELS method. In our opinion, a bank can only achieve its current marketleading position if it receives the best rating of all the factors included in the analysis and performs better than the average of the banking sector in all respects. This assumption was not substantiated, as the examined bank did not receive the best rating for several items. Based on the calculations, it can be seen that it did not perform above the average of the banking sector in all analytical factors, but nevertheless it is able to maintain its market-leading position for years due to its long-term strategy and competent management. In our view, efficiency levels remain sustainable with either higher profits or lower operating costs.

Of course, the impact of COVID-19 on the current economic situation must also be examined. It is the responsibility of the institutions concerned to continue to support both the household and corporate sectors, with a special focus on small and medium-sized enterprises, and to prioritize the basic needs of their clients. It is not yet clear what impact the isolation measures taken as a result of the spread of the virus and the damage to the economy, consumer decline due to unemployment and insolvency will have. All the countries of the world, including Hungary, have taken significant economic measures, one of the main participants of which is commercial and credit banks. A moratorium on repayment of loans taken out by individuals and companies to date will be introduced in Hungary by the end of the year, which has been accepted by commercial banks. The maturity of short-term business loans has been extended until June 30, 2021. The maximum APR for consumer loans is set at a maximum of five percentage points relative to the MNB's base rate.

\section{References}

1. BCBS (2006) Basel Committee on Banking Supervision. International Convergence of Capital Measurement and Capital Standards

2. Fazekas, Zs. (2009) A Bázel 2 pénzügyi szabályozási rendszer. Budapesti Gazdasági Főiskola Külkereskedelmi Kar https://docplayer.hu/7018519-A-bazel-2penzugyi-szabalyozasi-rendszer.html (download: 05.02.2021.)

3. John C. Hull (2015): Risk Management and Financial Institutions

4. Kiss, H.J. and Homolya D. (2014): On the optimal design of operational risk data. consortiums, Journal of Operational Risk, 9 (1), pp. 33-55. (download: 
https://www.scopus.com/inward/record.uri?eid=2-s2.0-84973894708\&partner $\mathrm{ID}=40 \& \mathrm{md} 5=4 \mathrm{c} 59824595 \mathrm{c} 35076 \mathrm{a} 1 \mathrm{bde} 8 \mathrm{af0eda} 015 \mathrm{c}$ )

5. KPMG (2013): Basel 4 - Emerging from the mist?

6. Massimiliano Coluccia and Marco Franchini and Elisa Quinto: (2020) Basel 4 and the reduction in RWA variability: capital buffers and capital erosion

7. Rai, E. (2010). A study of Camel analysis of commercial banks.

8. Seregdi, L. (1993) Pénzintézetek komplex elemzési és értékelési rendszere, Bank és tőzsde, 1993

9. Sulyok-Pap, M. (2006) Banküzemtan, Pénzügyi Tanácsadó és Szolgáltató Kft., Budapest.

10. Szemán J. (2015) A magyar bankrendszer CAMELS típusú elemzése

11. Szombati, A. (2010) Bázel III. rendszerszintű hatásai itthon és Európában. MNB szemle https://www.mnb.hu/letoltes/szombati.pdf (download: 04.03.2021) 12. Tajti Zs. (2011) A bázeli ajánlások és a tőkemegfelelési direktíva (CRD) formálódása 